\title{
Effects of feed restriction and prolactin-release inhibition at drying-off on susceptibility to new intramammary infection in cows
}

\author{
S. Ollier, ${ }^{*} X$. Zhao, $†$ and P. Lacasse ${ }^{* 1}$ \\ *Dairy and Swine Research and Development Centre, Agriculture and Agri-Food Canada, Sherbrooke, Quebec, Canada J1M 0C8 \\ †Department of Animal Science, McGill University, Sainte-Anne-de-Bellevue, Quebec, Canada H9X 3V9
}

\begin{abstract}
A cow's risk of acquiring a new intramammary infection during the dry period increases with milk production at drying-off. A method commonly used to reduce milk production is a drastic reduction in feed supply in the days that precede drying-off. Milk production can also be reduced by inhibiting the lactogenic signal driven by prolactin (PRL). This study aimed to compare the effects of these 2 drying-off procedures on milk production, metabolism, and susceptibility to intramammary infection in cows. A total of 21 Holstein cows in late lactation were assigned to 1 of 3 treatments based on milk yield, somatic cell count, and parity. The cows were fed a lactation diet until drying-off (control), only dry hay during the last $5 \mathrm{~d}$ before drying-off $(\mathrm{DH})$, or the same diet as the control cows but with twice-daily i.m. injections of $4 \mathrm{mg}$ of quinagolide, a specific inhibitor of PRL release, from $5 \mathrm{~d}$ before drying-off until $13 \mathrm{~d}$ after (QN). On d 1 to 7 after the last milking, the cows were challenged by daily teat dipping in a solution containing Streptococcus agalactiae at $5 \times 10^{7} \mathrm{cfu} / \mathrm{mL}$. Quinagolide induced a decrease in PRL concentration in blood on all the injection days. Blood PRL was also depressed in the hay-fed cows before drying-off. Both the QN and DH treatments induced a decrease in milk production, which at drying-off averaged 12.0, 10.0, and $21.7 \mathrm{~kg} / \mathrm{d}$ for the QN, DH, and control cows, respectively. The DH treatment decreased blood concentration of glucose and increased blood concentrations of $\beta$-hydroxybutyrate and nonesterified fatty acids before drying-off. Somatic cell count at drying-off was greater in the milk of the QN cows than in that of the control cows but after drying-off was greater in the mammary secretions of the control cows than in those of the QN cows. The number of $S$. agalactiae colonies found in mammary secretions on d 8 and 14 after the last milking was lower for the QN cows than for the control cows. The percentage of $S$. agalactiae-infected quarters
\end{abstract}

Received May 30, 2014.

Accepted October 8, 2014.

${ }^{1}$ Corresponding author: Pierre.Lacasse@agr.gc.ca was also lower in the QN cows than in the control cows and on d 14 averaged 17.2, 33.7, and 57.5\% in the QN, $\mathrm{DH}$, and control cows, respectively. No differences between the DH and control groups were observed for either bacterial count or infection rate. In conclusion, this experiment shows that PRL-release inhibition could be an alternative for reducing milk production and improving resistance to intramammary infection at drying-off.

Key words: quinagolide, dry period, dairy cow

\section{INTRODUCTION}

The lactation cycle of the dairy cow requires a dry period for optimal milk production in the subsequent lactation. However, the susceptibility to new IMI is high during the first 3 wk of the dry period (Eberhart, 1986). Even though milk is no longer removed, the mammary gland temporarily continues to synthesize milk, causing milk accumulation and leakage via the teats and thereby facilitating the entry of microorganisms into the mammary gland (Oliver and Sordillo, 1989). Consequently, the risk of acquiring a new infection during the dry period increases rapidly with the level of milk production (Rajala-Schultz et al., 2005). As it is now common to dry off cows that are still producing 25 to $30 \mathrm{~kg} / \mathrm{d}$ of milk, it is important to develop strategies that reduce milk production before drying-off.

A common drying-off practice among farmers involves a drastic short-term reduction in feed supply in the days that precede drying-off. Although effective for rapidly reducing milk yield, this method creates a state of negative energy balance, especially in high-yielding cows. Accordingly, feeding only straw (Odensten et al., 2005) or hay (Bernier-Dodier et al., 2011) at drying-off caused metabolic stress, as indicated by an increase in plasma NEFA concentration comparable with the increase that can be observed in early lactation (Loiselle et al., 2009). The linkage between metabolic stress in early lactation and health disorders such as mastitis is well documented (Pryce et al., 1998; Ingvartsen et al., 2003). Carbonneau et al. (2012) and Ster et al. (2012) reported that immune functions such as periph- 
eral blood mononuclear cell (PBMC) proliferation and cytokine release were inhibited by serum obtained from periparturient cows and that this inhibition was related directly to NEFA concentration in the serum. Accordingly, the present authors reported in a previous paper that serum harvested from feed-restricted cows in late lactation reduced PBMC proliferation and IL-4 production (Ollier et al., 2014). It is therefore possible that part of the gain in disease resistance obtained by reducing milk production at drying-off by means of feed restriction is lost as the result of immunosuppression.

Milk production can also be reduced by decreasing the lactogenic signals driving milk production. Lacasse et al. (2011) recently showed that inhibiting prolactin (PRL) secretion using the dopamine agonist quinagolide gradually decreased milk production in cows at peak lactation. When applied to cows in late lactation, the same approach induced a sharp decrease in milk production within $24 \mathrm{~h}$, and several indicators suggested that involution had been hastened (Ollier et al., 2013, 2014). This approach did not affect NEFA concentration or PBMC proliferation. The results of that experiment suggest that inhibiting PRL secretion could be a valuable alternative for reducing milk production before drying-off without disturbing the metabolism and immune functions of the cow, but the protective effect of PRL-release inhibition against IMI has not been yet assessed. The present study aimed to compare the effects of PRL-release inhibition as a drying-off procedure with those of a drastic reduction in feed supply in the days preceding drying-off on mammary gland susceptibility to new infection in cows.

\section{MATERIALS AND METHODS}

\section{Animals and Experimental Design}

The experiment was conducted in accordance with the guidelines of the Canadian Council on Animal Care (1993). A total of 21 Holstein cows in late lactation (329 \pm 12 DIM at drying-off) housed at Agriculture and Agri-Food Canada's Dairy and Swine Research and Development Centre (Sherbrooke, QC, Canada) were assigned to 1 of 3 treatments according to their milk yield, SCC, and parity (1 primiparous and 6 multiparous cows per treatment). The cows were housed in individual tie stalls and were fed ad libitum 1) a late-lactation diet (containing grass silage, corn silage, dry hay, corn grain, soybean meal, and nonmineral and mineral supplements) until drying-off (control; $\mathrm{n}=7$ ), 2) only dry hay during the last $5 \mathrm{~d}$ before drying-off $(\mathbf{D H} ; \mathrm{n}=7)$, or 3) the same late-lactation diet as the control cows but with twice-daily (at 0930 and $2130 \mathrm{~h}$ ) i.m. injections of $4 \mathrm{mg}$ of quinagolide (Ferring, Wallisellen, Switzerland) from 5 d before drying-off until $13 \mathrm{~d}$ after $(\mathbf{Q N} ; \mathrm{n}=7)$. The control and $\mathrm{DH}$ cows received injections of the solvent (water). After dryingoff, all 21 cows were fed ad libitum a dry-period diet containing (on a DM basis) $69.9 \%$ dry hay and $30.1 \%$ TMR (containing corn silage, soybean meal, and mineral supplement). The compositions of the late-lactation TMR, dry hay, and dry-period TMR are presented in Table 1. Feed intake was recorded daily for each cow throughout the experiment, and each cow's BW was determined at the start and at the end of the experiment. The cows were milked twice daily, at 0800 and $2000 \mathrm{~h}$, and milk yield was recorded at each milking during the last 2 wk before drying-off. Any given experimental day started after the a.m. milking or sampling and ended at the next a.m. milking or sampling. Accordingly, the last milking was performed on the morning of $d-1$ and the sampling of the next morning was called $\mathrm{d} 1$. A summary of the experimental design and sampling is presented in Supplemental Figure S1 (http://dx.doi. org/10.3168/jds.2014-8426).

\section{Bacterial Challenge}

No antibiotic dry-cow therapy was administered at drying-off. On d 1 to 7 after the last milking, the cows were challenged by daily dipping each teat in a suspension containing Streptococcus agalactiae (strain ATCC 27956, American Type Culture Collection, Manassas, VA) at $5 \times 10^{7} \mathrm{cfu} / \mathrm{mL}$. Challenge suspension was

Table 1. Composition of diets

\begin{tabular}{lccc}
\hline Item & $\begin{array}{c}\text { Late-lactation } \\
\text { TMR }\end{array}$ & $\begin{array}{c}\text { Dry } \\
\text { hay }\end{array}$ & $\begin{array}{c}\text { Dry-period } \\
\text { TMR }\end{array}$ \\
\hline Chemical composition, \% of DM & & & \\
CP & 13.9 & 10.4 & 21.3 \\
ADF & 19.8 & 42.6 & 17.5 \\
NDF & 31.9 & 70.2 & 29.7 \\
P & 0.41 & 0.24 & 0.54 \\
K & 1.51 & 2.26 & 1.39 \\
Ca & 0.76 & 0.24 & 0.78 \\
$\mathrm{NE}_{\mathrm{L}}, \mathrm{Mcal} / \mathrm{kg}$ of DM & 1.57 & 1.20 & 1.64 \\
\hline
\end{tabular}


prepared daily by incubating $S$. agalactiae from frozen bacterial stock $\left(-80^{\circ} \mathrm{C}\right)$ in $25 \mathrm{~mL}$ of trypticase soy broth (Becton, Dickinson and Company, Mississauga, ON, Canada) at $37^{\circ} \mathrm{C}$ for $18 \mathrm{~h}$. A volume of this overnight culture was then transferred into fresh trypticase soy broth to obtain an optical density at $600 \mathrm{~nm}\left(\mathbf{O D}_{600 \mathrm{~nm}}\right)$ of 0.1 and grown at $37^{\circ} \mathrm{C}$ for approximately $2.5 \mathrm{~h}$, until $\mathrm{OD}_{600 \mathrm{~nm}}$ reached 0.450 to 0.500 in the exponential growth phase. Bacterial concentration of this suspension was estimated by using the relationship between $\mathrm{OD}_{600 \mathrm{~nm}}$ and colony-forming units established before the animal trial. The bacterial suspension was further diluted in sterile $0.9 \%$ sodium chloride (Baxter Corporation, Toronto, ON, Canada) to obtain approximately $5 \times 10^{7} \mathrm{cfu} / \mathrm{mL}$. For each cow, $40 \mathrm{~mL}$ of the diluted suspension were transferred into a sterile $60-\mathrm{mL}$ container for teat dipping. An aliquot of the inoculum $(100 \mu \mathrm{L}$ of a $10^{-5}$ dilution) was plated on tryptic soy agar (Becton, Dickinson and Company) and plates were incubated at $37^{\circ} \mathrm{C}$ for $24 \mathrm{~h}$ to ascertain the bacterial concentration of challenge suspension. These bacterial counts confirmed that the bacterial suspension contained $5.7 \times 10^{7} \mathrm{cfu} /$ $\mathrm{mL}$ on average.

\section{Milk and Mammary Secretion Collection}

Milk samples $(60 \mathrm{~mL})$ were manually collected from each quarter just before the a.m. milking on $\mathrm{d}-7,-5$, -2 , and -1 . Mammary secretions $(60 \mathrm{~mL})$ were manually collected from each quarter at $0730 \mathrm{~h}$ on $\mathrm{d} 8$ and 14 after the last milking. These samples were used to measure SCC. Aseptic milk and mammary secretion samples were also harvested on $\mathrm{d}-7,-1,8$, and 14 for bacteriological analysis using the procedure suggested by the National Mastitis Council (1996). After the foremilk was discarded, a 10-mL milk sample was collected from each individual quarter in a sterile $15-\mathrm{mL}$ tube and kept on ice until plating.

\section{SCC and Bacterial Count Determination in Milk and Mammary Secretions}

Somatic cell count was determined from whole milk in a commercial laboratory (Valacta Inc., Ste-Anne-deBellevue, QC, Canada). Mammary secretion SCC was determined using an automatic cell counter (DeLaval International AB, Tumba, Sweden) as previously described (Ollier et al., 2014).

For bacterial count determination, $100 \mu \mathrm{L}$ of aseptic milk and mammary secretion samples were plated on tryptic soy agar supplemented with $5 \%$ sheep blood (Becton, Dickinson and Company) just after their collection. Plates were then incubated at $37^{\circ} \mathrm{C}$ for $24 \mathrm{~h}$ before colony count. Streptococcus agalactiae were identified by hemolytic pattern and colony color and morphology. When other types of colony were present, they were counted and the bacteria identified. Sample dilutions were performed from samples stored at $-20^{\circ} \mathrm{C}$ in sterile $0.9 \%$ sodium chloride when more than 300 colonies grown on agar. Each sample and dilution was plated in duplicate. A quarter was reported as infected when the milk or mammary secretion sample contained S. agalactiae at $\geq 20 \mathrm{cfu} / \mathrm{mL}$.

\section{Blood Collection}

Caudal blood samples were taken at $0730 \mathrm{~h}$, just before the a.m. milking or milk sample collection, on $\mathrm{d}-7$ to -1 and on $\mathrm{d} 1,3,5,8,10$, and 14 in Vacutainer collection tubes without additives and in EDTA-coated Vacutainer tubes (Becton, Dickinson and Company). All the blood tubes without additives were left at room temperature for approximately $2 \mathrm{~h}$ to allow clotting before centrifugation $\left(1,900 \times g, 4^{\circ} \mathrm{C}, 15 \mathrm{~min}\right)$. Then, the serum was stored at $-20^{\circ} \mathrm{C}$ until determination of PRL concentration. The blood tubes containing EDTA were placed on ice immediately after collection and centrifuged $\left(1,900 \times g, 4^{\circ} \mathrm{C}, 15 \mathrm{~min}\right)$ within $30 \mathrm{~min}$. Then, the plasma was stored at $-20^{\circ} \mathrm{C}$ until determination of glucose, NEFA, and BHBA concentrations.

\section{Prolactin Concentration in Serum}

Serum PRL concentration was measured by RIA as described by Bernier-Dodier et al. (2011). Bovine PRL, rabbit antiserum specific for bovine PRL, and goat anti-rabbit gamma globulin were purchased from the National Hormone and Peptide Program (HarborUCLA Medical Center, Torrance, CA). The intra- and interassay coefficients of variation were 2.4 and $1.7 \%$, respectively.

\section{Metabolite Concentrations in Plasma}

Plasma glucose concentration was determined as previously described (Loiselle et al., 2009) using a glucose assay kit (Roche Diagnostics, Laval, QC, Canada) employing a modification of the glucose oxidase/peroxidase method described by Trinder (1969). The intraand interassay CV were 1.2 and $3.5 \%$, respectively.

Plasma NEFA and BHBA concentration were determined as described in Ollier et al. (2014). The intra- and interassay coefficients of variation were 3.7 and $6.8 \%$ for NEFA and 2.0 and $2.6 \%$ for BHBA, respectively.

\section{Statistical Analysis}

All data except for infection rate were analyzed separately for the pretreatment period $(\mathrm{d}<-5)$, the 
pre-drying-off treatment period ( $\mathrm{d}-5$ to -1 ), and the post-drying-off treatment period ( 1 to 14 ) by ANOVA using the MIXED procedure of the SAS software package (SAS Institute Inc., Cary, NC). Time was used as a repeated effect, and cow(treatment) was used as the subject. Bacterial count and SCC were $\log _{10^{-}}$ transformed before analysis. Infection rate data were analyzed using the GLIMMIX procedure of SAS. For all data, orthogonal contrasts were used to compare least squares means between the $\mathrm{QN}$ and control groups and between the $\mathrm{DH}$ and control groups. The least squares means of the QN and DH groups were compared using the Tukey-Kramer adjustment. Differences were considered statistically significant when $P<0.05$.

\section{RESULTS}

Basal blood PRL concentration was similar for the 3 groups of animals during the pretreatment period (Figure 1). On all the injection days, PRL concentration in the quinagolide-treated cows was lower than that in the control cows $(P<0.001)$ and DH cows $(P=0.006$ between $\mathrm{d}-5$ and -1 , and $P=0.001$ between $\mathrm{d} 1$ and 14) and averaged $7 \%$ of that of the control cows during the treatment period ( $\mathrm{d}-5$ to 14$)$. The concentration of PRL in the blood of the DH cows was also depressed $(P=0.009)$ and averaged $62 \%$ of that of the control cows during the pre-drying-off treatment period $(\mathrm{d}-5$ to -1). After drying-off, however, PRL concentration was again similar for the $\mathrm{DH}$ and control cows.

During the pretreatment period, DMI was similar for the 3 groups of animals (data not shown). During the pre-drying-off treatment period, the quinagolidetreated cows ate less than the control cows did $(-31 \%$, $P<0.001)$. As expected, DMI was lower in the $\mathrm{DH}$ cows than in the control cows $(-58 \%, P<0.001)$ and QN cows $(-39 \%, P<0.001)$ during the pre-dryingoff treatment period. After drying-off, DMI was again similar for the 3 groups. At the start and end of the experiment, BW was similar for the 3 groups of cows (data not shown).

Milk production was similar for the 3 groups of animals before the start of the treatments $(22.9 \pm 0.7 \mathrm{~kg} / \mathrm{d}$ on average between $d-10$ and -6 ; Figure 2). During the pre-drying-off treatment period, a treatment $\times$ time interaction $(P<0.001)$ was present. From the first injection day, quinagolide reduced $(P<0.001)$ milk production, which was $45 \%$ lower in the QN cows than in the control cows just before drying-off (on $\mathrm{d}-1$ ). The DH treatment also reduced $(P<0.001)$ milk production, which was $54 \%$ lower in the DH cows than in the control cows on $d-1$. Milk production was similar for the $\mathrm{QN}$ and $\mathrm{DH}$ groups during the pre-drying-off treatment period, with the exception that on $\mathrm{d}-5$, the

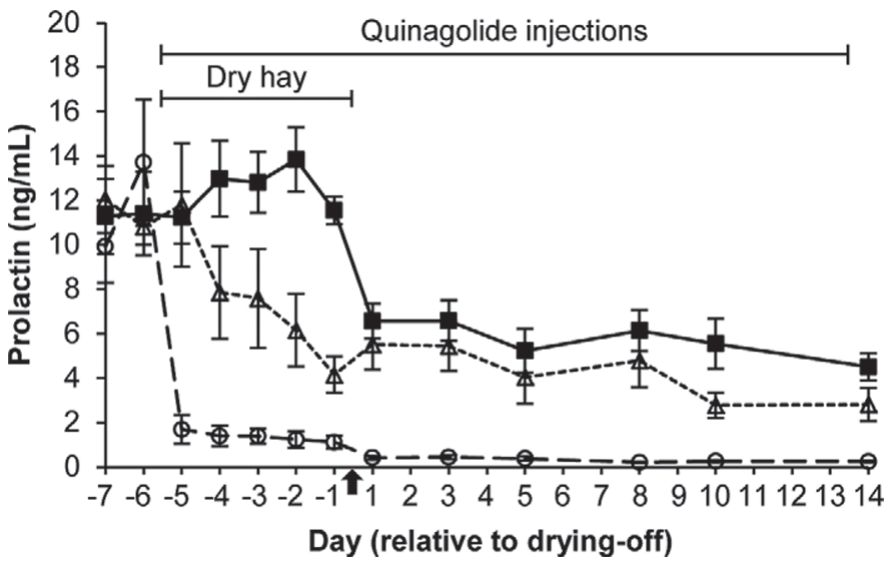

Figure 1. Basal blood concentration of prolactin in cows injected twice daily with $4 \mathrm{mg}$ of quinagolide from $5 \mathrm{~d}$ before drying-off until $13 \mathrm{~d}$ after $(\mathrm{O}$, long-dashed line; $\mathrm{n}=7)$, cows fed only dry hay for the last $5 \mathrm{~d}$ before drying-off ( $\Delta$, short-dashed line; $\mathrm{n}=7$ ), and control cows $(\mathbf{\square}$, solid line; $\mathrm{n}=7)$. Drying-off is indicated by an arrow. Data are presented as least squares means \pm standard error of the means.

milk production of the $\mathrm{QN}$ cows was lower $(P=0.015)$ than that of the DH cows.

The effects of the treatments on plasma glucose, NEFA, and BHBA concentrations are presented in Figure 3. No differences between the 3 groups of animals were observed for all 3 of these parameters during the pretreatment period (on $\mathrm{d}-7$ and -6 ). As expected, plasma glucose concentration was lower in the $\mathrm{DH}$ cows than in the QN cows $(P<0.001)$ and control cows $(P=0.005)$ during the pre-drying-off treatment period (Figure 3A). Glucose concentration tended to be greater $(P=0.054)$ in the quinagolide-treated cows than in the control cows before drying-off. After

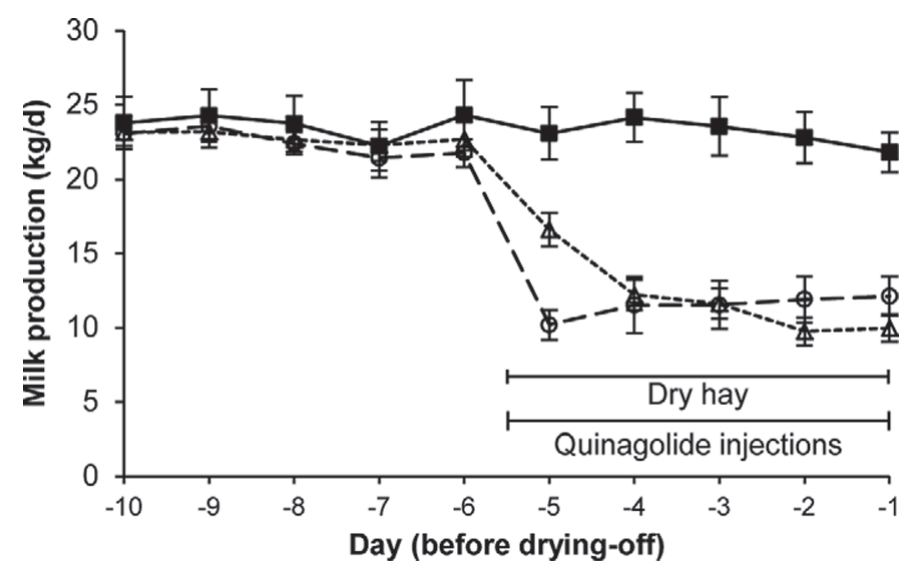

Figure 2. Milk production during the last $10 \mathrm{~d}$ of lactation in cows injected twice daily with $4 \mathrm{mg}$ of quinagolide from $5 \mathrm{~d}$ before dryingoff until $13 \mathrm{~d}$ after $(\mathrm{O}$, long-dashed line; $\mathrm{n}=7)$, cows fed only dry hay for the last $5 \mathrm{~d}$ before drying-off $(\Delta$, short-dashed line; $\mathrm{n}=7)$, and control cows $(\boldsymbol{\square}$, solid line; $\mathrm{n}=7$ ). Data are presented as least squares means \pm standard error of the means. 
drying-off, plasma glucose concentration was similar for the 3 groups. Feed restriction induced a sharp increase in plasma NEFA concentration, which was greater $(P$ $<0.001)$ in the DH cows than in the $\mathrm{QN}$ and control cows during the pre-drying-off treatment period (Figure 3B). After drying-off, NEFA concentration in the $\mathrm{DH}$ cows decreased and was similar to that in the QN and control cows. No differences between the QN and control groups were observed before and after dryingoff. A treatment $\times$ time interaction $(P<0.001)$ was present for plasma BHBA concentration during both the pre-drying-off and post-drying-off treatment periods (Figure 3C). At the beginning of the treatment period, BHBA concentration was transiently lower in the blood of the DH cows than in that of the QN and control cows $(P=0.006$ and $P=0.022$, respectively, on $\mathrm{d}-5)$. However, from $\mathrm{d}-4$, BHBA concentration in the $\mathrm{DH}$ cows increased; it was greater in the $\mathrm{DH}$ cows than in the QN cows on $\mathrm{d}-2$ and $-1(P=0.019$ and $P=0.013$, respectively) and tended to be greater $(P$ $=0.091)$ in the $\mathrm{DH}$ cows than in the control cows on $\mathrm{d}-1$. After drying-off, plasma BHBA concentration in the $\mathrm{DH}$ cows was greater than that in the QN cows on d $1(P<0.001)$ and that in the control cows between $\mathrm{d} 1$ and $14(P=0.003)$. No differences between the QN and control groups were observed before and after drying-off.

Before the start of the bacterial challenge, all quarters of the animals in all 3 groups were totally free of $S$. agalactiae. After the teats were dipped once a day for $7 \mathrm{~d}$ in a $S$. agalactiae solution, fewer bacteria were found in the mammary secretions of the quinagolidetreated cows $(P=0.039$ and $P=0.023$ on d 8 and 14 , respectively) than in the secretions of the control cows (Figure 4A). The percentage of S. agalactiae-infected quarters was also greater in the control cows than in the QN cows on $\mathrm{d} 8$ (by 2.5 fold, $P=0.015$ ) and $\mathrm{d} 14$ (by 3.3 fold, $P=0.015$; Figure $4 \mathrm{~B}$ ). No differences between the $\mathrm{DH}$ and control groups were observed for both bacterial count and infection rate. Otherwise, before the onset of treatments, Corynebacterium bovis was also found in 13 quarters ( 3 control, $4 \mathrm{QN}$, and 6 DH quarters) in 10 cows. Among these 10 cows, the $S$. agalactiae infection rate was $54 \%$ for $C$. bovis-positive quarters and $52 \%$ for $C$. bovis-negative quarters.

Somatic cell count was similar among the 3 groups of animals before the start of the treatments $(\mathrm{d}-7$; Figure 5). A treatment $\times$ time interaction $(P=0.002)$ was present for SCC in milk before drying-off. The SCC in milk was greater for the QN cows than for the control cows on $\mathrm{d}-5(P=0.003)$ and $-1(P=0.007)$ and greater for the QN cows than for the DH cows on $\mathrm{d}-5(P=0.024)$. The SCC in milk was also greater $(P=0.025)$ for the DH cows than for the control cows
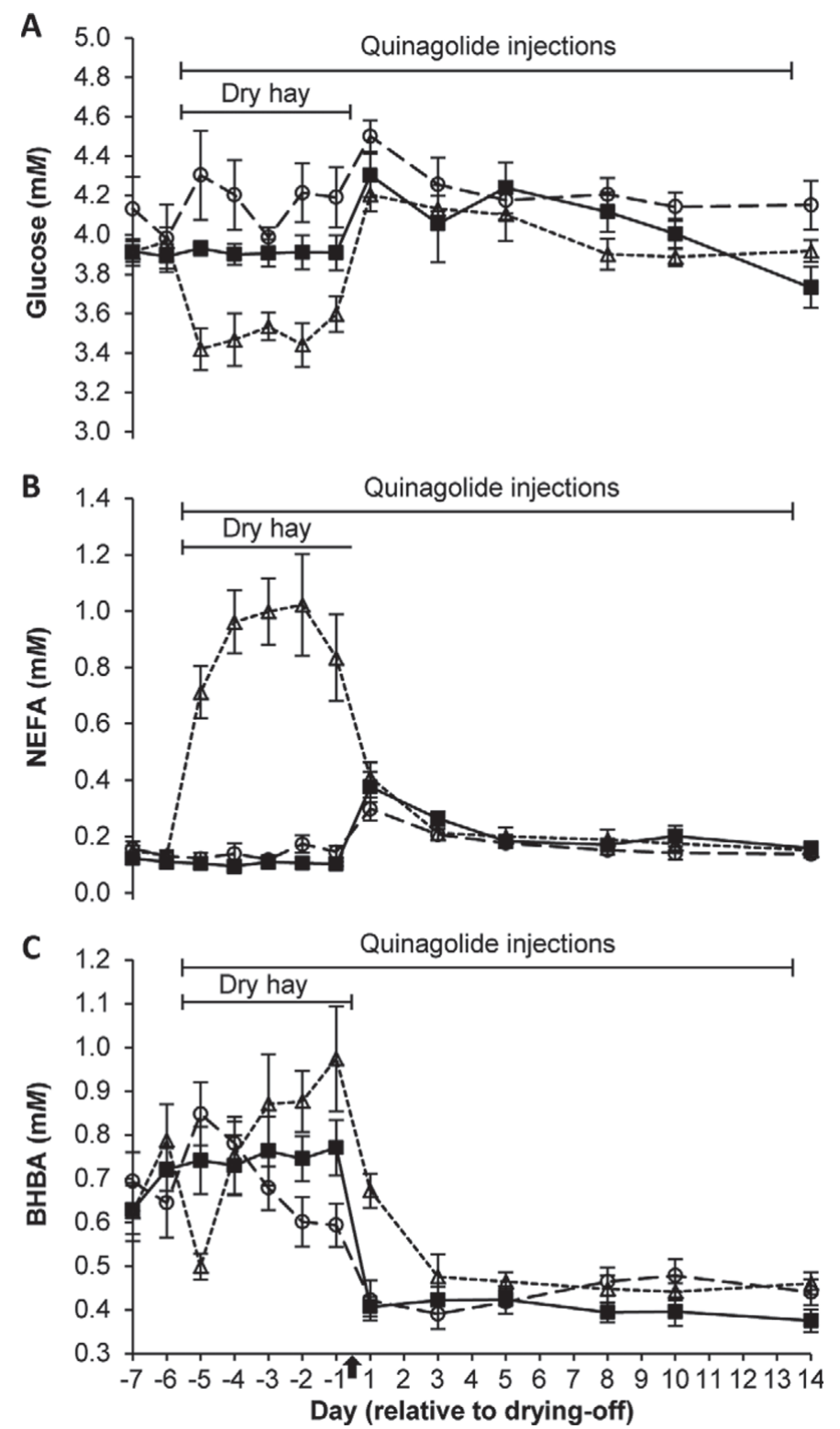

Figure 3. Blood concentrations of glucose (A), NEFA (B), and BHBA (C) in cows injected twice daily with $4 \mathrm{mg}$ of quinagolide from $5 \mathrm{~d}$ before drying-off until $13 \mathrm{~d}$ after $(\mathrm{O}$, long-dashed line; $\mathrm{n}=7)$, cows fed only dry hay for the last $5 \mathrm{~d}$ before drying-off $(\Delta$, short-dashed line; $\mathrm{n}=7$ ), and control cows $(\mathbf{\square}$, solid line; $\mathrm{n}=7$ ). Drying-off is indicated by an arrow. Data are presented as least squares means \pm standard error of the means.

on $\mathrm{d}-1$. After drying-off (on d 8 and 14), the SCC in mammary secretions was greater $(P=0.011)$ for the control cows than for the QN cows, reflecting the high infection rate in the control cows.

\section{DISCUSSION}

In the present experiment, as in previous studies by the present authors (Ollier et al., 2013, 2014), quina- 

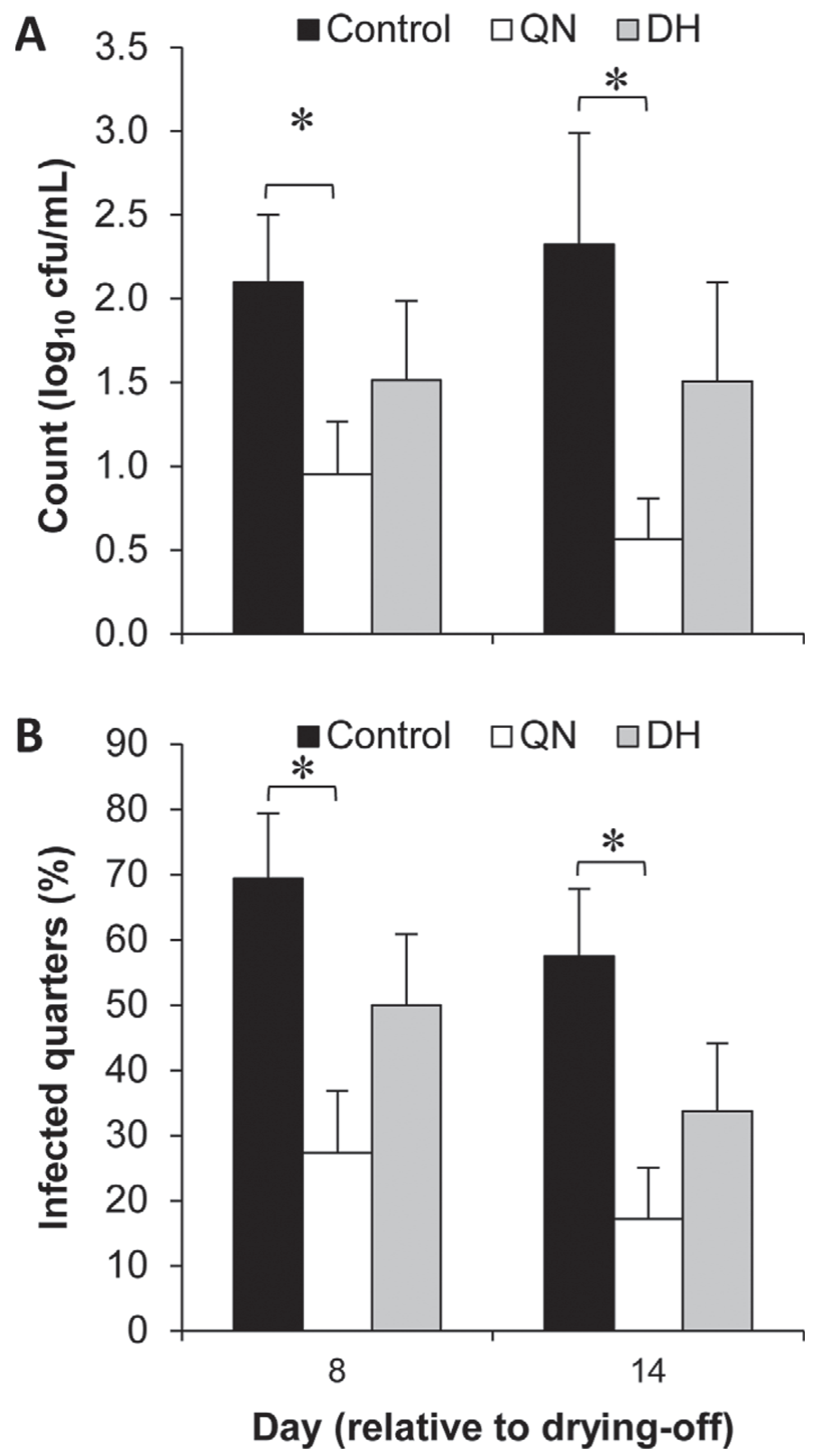

Figure 4. Streptococcus agalactiae count (A) and infection rate (B) in the mammary secretions of cows injected twice daily with $4 \mathrm{mg}$ of quinagolide from $5 \mathrm{~d}$ before drying-off until $13 \mathrm{~d}$ after ( $\mathrm{QN} ; \mathrm{n}=7$ ), cows fed only dry hay for the last $5 \mathrm{~d}$ before drying-off $(\mathrm{DH} ; \mathrm{n}=7)$, and control cows $(\mathrm{n}=7)$. All teats of each cow were dipped daily, from d 1 to 7 after the last milking, in a solution containing S. agalactiae at $5 \times 10^{7} \mathrm{cfu} / \mathrm{mL}$. Bacterial count data are presented as least squares means \pm standard error of the mean of $\log _{10}$-transformed values. Prior to $\log _{10}$ calculation, +1 was added to bacterial counts. A quarter was reported as infected when the mammary secretion sample contained S. agalactiae at $\geq 20 \mathrm{cfu} / \mathrm{mL}$. Infection rate data are presented as least squares means \pm standard error of the means. Significant differences between treatments are indicated $(* P<0.05)$.

golide injections drastically reduced serum PRL concentration before and after drying-off. The effects of both the QN and DH treatments on milk production, DMI, and metabolites were similar to those observed

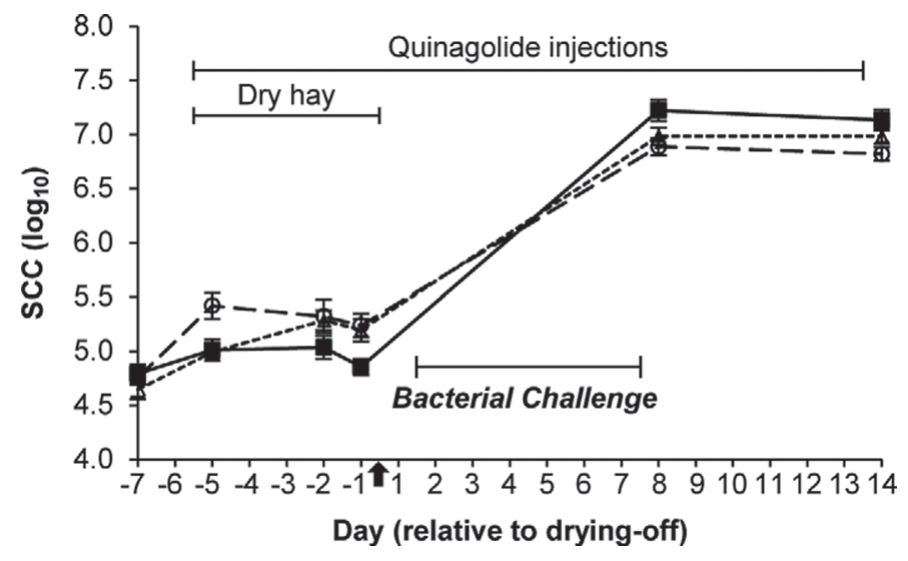

Figure 5. Somatic cell count in milk and mammary secretions of cows injected twice daily with $4 \mathrm{mg}$ of quinagolide from $5 \mathrm{~d}$ before drying-off until $13 \mathrm{~d}$ after $(\mathrm{O}$, long-dashed line; $\mathrm{n}=7$ ), cows fed only dry hay for the last $5 \mathrm{~d}$ before drying-off $(\Delta$, short-dashed line; $\mathrm{n}=$ 7 ), and control cows $(\boldsymbol{\square}$, solid line; $\mathrm{n}=7$ ). All teats of each cow were dipped daily, from d 1 to 7 after the last milking, in a solution containing Streptococcus agalactiae at $5 \times 10^{7} \mathrm{cfu} / \mathrm{mL}$. Drying-off is indicated by an arrow. Data are presented as least squares means \pm standard error of the means of $\log _{10}$-transformed values.

previously and are discussed in Ollier et al. (2014). Interestingly, feed restriction and quinagolide injections reduced milk production at drying-off to a very similar extent, and thus the effects of infection susceptibility could be compared independent of milk production level.

Quinagolide injections reduced both the number of bacteria found in mammary secretions and the percentage of quarters infected by $S$. agalactiae. Several studies have reported that susceptibility to new IMI during the dry period increases with the level of milk production at drying-off (McDougall, 2003; Dingwell et al., 2004; Rajala-Schultz et al., 2005; Newman et al., 2010). The formation of a teat-canal keratin plug prevents the penetration of bacteria and is therefore an important protective factor for the mammary gland (Cousins et al., 1980; Capuco et al., 1992). Lower milk production at drying-off is associated with rapid closure of the teat canal (Dingwell et al., 2004; Odensten et al., 2007a). Mammary gland involution early in the dry period also affects the rate of new IMI in the dry period (Dingwell et al., 2003). Indeed, as involution progresses, changes occur in the composition and $\mathrm{pH}$ of milk (Sordillo et al., 1987) that inhibit bacterial growth (Bushe and Oliver, 1987). In Ollier et al. (2014), all indicators showed a hastening of mammary gland involution in quinagolide-treated cows. In the present study, SCC in milk was greater for the QN cows than for the control cows before drying-off but was not evaluated during the first week of the dry period so as not to disturb the keratin plug. In Ollier et al. (2014), SCC in the mammary secretions of quinagolide-treated cows tended to 
increase faster after drying-off. Neutrophils, lymphocytes and macrophages make up a high proportion of milk somatic cells and are important components of the mammary gland's first line of defense against bacterial colonization. It is therefore reasonable to assume that a high number of these cells may also help prevent colonization of the mammary gland. The lower milk production and greater SCC at drying-off on the one hand and the hastening of teat-canal closure and mammary gland involution on the other probably explain the protective effect of quinagolide against IMI.

Even though feed restriction decreased milk production at drying-off, that method failed to reduce bacterial count and infection rate. In a previous study by the present authors, feed restriction was also associated with a hastening of mammary gland involution (Ollier et al., 2014). Although McDougall (2003) reported that lower milk production at drying-off was associated with a lower incidence of clinical mastitis during the dry period, he also reported a greater incidence of mastitis in herds where feed restriction was imposed at the time of drying-off. Reducing pasture allowance from 14 to $6 \mathrm{~kg}$ of $\mathrm{DM} / \mathrm{d}$ hastened teat-canal closure but did not affect the incidence of IMI and clinical mastitis (Summers et al., 2004). In the present study and in Ollier et al. (2014), feed restriction caused metabolic stress, as highlighted by lower blood glucose and greater concentrations of NEFA and BHBA. Ster et al. (2012) showed that a high concentration of NEFA inhibits the proliferation of and cytokine secretion by PBMC as well as the oxidative burst of PMNL. Accordingly, PBMC proliferation and IL-4 release were inhibited by incubation in the serum of hay-fed cows (Ollier et al., 2014). In addition, Odensten et al. (2007b) reported an important increase in plasma cortisol in straw-fed cows at drying-off. The immunosuppressive effects of glucocorticoids are well known and affect several bovine leukocyte functions (Burton and Kehrli, 1996; Nonnecke et al., 1997; Konig et al., 2006). Therefore, an impairment of the immune system may have masked the protective effect of lower milk production in the feed-restricted cows in the present experiment.

Although S. agalactiae has been eliminated from most herds in Canada, its use as a challenge pathogen offers several advantages. Streptococcus agalactiae is a highly infectious pathogen, and in this challenge model it gave an overall infection rate on d 14 of $36 \%$ of the quarters and $76 \%$ of the cows. The pathogen was not present in the herd before the challenge, and therefore all infections were acquired during the challenge period. Because the pathogen is not present in the environment, exposure could be controlled. Finally, all infections were treated with standard dry-cow therapy, and none of the cows were infected at the next calving. The authors believe that this infection model can be useful for evaluating mammary gland resistance to infection after drying-off.

In conclusion, the results of this experiment show that both feed restriction and PRL-release inhibition decreased milk production before drying-off. However, only PRL-release inhibition was able to reduce susceptibility to IMI in a $S$. agalactiae challenge. This finding supports the authors' hypothesis that part of the gain in disease resistance obtained by reducing milk production by means of feed restriction is lost as the result of immunosuppression. Nevertheless, further research is required to avoid daily injection of the PRL inhibitor and to determine whether these drying-off procedures have an effect on the incidence of new IMI at drying-off in a commercial farm environment.

\section{ACKNOWLEDGMENTS}

The authors thank the following people (all from Agriculture and Agri-Food Canada, Sherbrooke, QC, Canada): Lisette St-James, Véronique Roy, Noémie Vanacker, and Thomas Damon for providing technical assistance; and the dairy barn staff for taking care of the cows. The authors also thank the National Hormone and Peptide Program and A. F. Parlow (Harbor-UCLA Medical Center, Torrance, CA) for providing the bovine PRL and antibodies. This research was financially supported by the Canadian Bovine Mastitis Research Network (St-Hyacinthe, QC, Canada), Dairy Farmers of Canada (Ottawa, ON, Canada), and Agriculture and Agri-Food Canada (Ottawa, ON, Canada).

\section{REFERENCES}

Bernier-Dodier, P., C. L. Girard, B. G. Talbot, and P. Lacasse. 2011. Effect of dry period management on mammary gland function and its endocrine regulation in dairy cows. J. Dairy Sci. 94:4922-4936.

Burton, J. L., and M. E. Kehrli Jr. 1996. Effects of dexamethasone on bovine circulating T lymphocyte populations. J. Leukoc. Biol. 59:90-99.

Bushe, T., and S. P. Oliver. 1987. Natural protective factors in bovine mammary secretions following different methods of milk cessation. J. Dairy Sci. 70:696-704.

Canadian Council on Animal Care. 1993. Guide to the Care and Use of Experimental Animals. Vol. 1. 2nd ed. E. D. Olfert, B. M. Cross, and A. A. McWilliam, ed. CCAC, Ottawa, ON, Canada.

Capuco, A. V., S. A. Bright, J. W. Pankey, D. L. Wood, R. H. Miller and J. Bitman. 1992. Increased susceptibility to intramammary infection following removal of teat canal keratin. J. Dairy Sci. $75: 2126-2130$.

Carbonneau, E., A. M. de Passillé, J. Rushen, B. G. Talbot, and P. Lacasse. 2012. The effect of incomplete milking or nursing on milk production, blood metabolites, and immune functions of dairy cows. J. Dairy Sci. 95:6503-6512.

Cousins, C. L., T. M. Higgs, E. R. Jackson, F. K. Neave, and F. H. Dodd. 1980. Susceptibility of the bovine udder to bacterial infection in the dry period. J. Dairy Res. 47:11-18.

Dingwell, R. T., D. F. Kelton, and K. E. Leslie. 2003. Management of the dry cow in control of peripartum disease and mastitis. Vet. Clin. North Am. Food Anim. Pract. 19:235-265. 
Dingwell, R. T., K. E. Leslie, Y. H. Schukken, J. M. Sargeant, L. L. Timms, T. F. Duffield, G. P. Keefe, D. F. Kelton, K. D. Lissemore, and J. Conklin. 2004. Association of cow and quarter-level factors at drying-off with new intramammary infections during the dry period. Prev. Vet. Med. 63:75-89.

Eberhart, R. J. 1986. Management of dry cows to reduce mastitis. J. Dairy Sci. 69:1721-1732.

Ingvartsen, K. L., R. Dewhurst, and N. Friggens. 2003. On the relationship between lactational performance and health: Is it yield or metabolic imbalance that cause production diseases in dairy cattle? A position paper. Livest. Prod. Sci. 83:277-308.

König, T., H. J. Schuberth, W. Leibold, and H. Zerbe. 2006. Dexamethasone depresses the expression of L-selectin but not the in vivo migration of bovine neutrophils into the uterus. Theriogenology $65: 1227-1241$.

Lacasse, P., V. Lollivier, R. M. Bruckmaier, Y. R. Boisclair, G. F. Wagner, and M. Boutinaud. 2011. Effect of the prolactin-release inhibitor quinagolide on lactating dairy cows. J. Dairy Sci. 94:1302-1309.

Loiselle, M. C., C. Ster, B. G. Talbot, X. Zhao, G. F. Wagner, Y. R. Boisclair, and P. Lacasse. 2009. Impact of postpartum milking frequency on the immune system and the blood metabolite concentration of dairy cows. J. Dairy Sci. 92:1900-1912.

McDougall, S. 2003. Management factors associated with the incidence of clinical mastitis over the non-lactation period and bulk tank somatic cell count during the subsequent lactation. N. Z. Vet. J. 51:63-72.

National Mastitis Council. 1996. Current Concept of Bovine Mastitis. 4th ed. National Mastitis Council, Madison, WI.

Newman, K. A., P. J. Rajala-Schultz, F. J. Degraves, and J. Lakritz. 2010. Association of milk yield and infection status at dry-off with intramammary infections at subsequent calving. J. Dairy Res. 77:99-106.

Nonnecke, B. J., J. L. Burton, and M. E. Kehrli Jr. 1997. Associations between function and composition of blood mononuclear leukocyte populations from Holstein bulls treated with dexamethasone. J. Dairy Sci. 80:2403-2410.

Odensten, M. O., B. Berglund, K. Persson Waller, and K. Holtenius. 2007a. Metabolism and udder health at dry-off in cows of different breeds and production levels. J. Dairy Sci. 90:1417-1428.
Odensten, M. O., Y. Chilliard, and K. Holtenius. 2005. Effects of two different feeding strategies during dry-off on metabolism in highyielding dairy cows. J. Dairy Sci. 88:2072-2082.

Odensten, M. O., K. Holtenius, and K. P. Waller. 2007b. Effects of two different feeding strategies during dry-off on certain health aspects of dairy cows. J. Dairy Sci. 90:898-907.

Oliver, S. P., and L. M. Sordillo. 1989. Approaches to the manipulation of mammary involution. J. Dairy Sci. 72:1647-1664.

Ollier, S., X. Zhao, and P. Lacasse. 2013. Effect of prolactin-release inhibition on milk production and mammary gland involution at drying-off in cows. J. Dairy Sci. 96:335-343.

Ollier, S., X. Zhao, and P. Lacasse. 2014. Effects of feed restriction and prolactin-release inhibition at drying off on metabolism and mammary gland involution in cows. J. Dairy Sci. 97:4942-4954.

Pryce, J. E., R. J. Esslemont, R. Thompson, R. F. Veerkamp, M. A Kossaibati, and G. Simm. 1998. Estimation of genetic parameters using health, fertility and production data from a management recording system for dairy cattle. Anim. Sci. 66:577-584.

Rajala-Schultz, P. J., J. S. Hogan, and K. L. Smith. 2005. Short communication: Association between milk yield at dry-off and probability of intramammary infections at calving. J. Dairy Sci. 88:577-579.

Sordillo, L. M., S. C. Nickerson, R. M. Akers, and S. P. Oliver. 1987. Secretion composition during bovine mammary involution and the relationship with mastitis. Int. J. Biochem. 19:1165-1172.

Ster, C., M. C. Loiselle, and P. Lacasse. 2012. Effect of postcalving serum nonesterified fatty acids concentration on the functionality of bovine immune cells. J. Dairy Sci. 95:708-717.

Summers, E. L., S. J. Lacy-Hulbert, J. H. Williamson, and B. P. Sugar. 2004. Influence of feeding level after drying off on incidence of mastitis and keratin plug formation in dairy cows. Proc. N.Z. Soc. Anim. Prod. 64:48-52.

Trinder, P. 1969. Determination of glucose in blood using glucose oxidase with an alternative oxygen acceptor. Ann. Clin. Biochem. 6:24-27. 